\title{
LOW-COST FLIGHTS AND TOURISM: DEVELOPMENT AND CHANGES FROM BERGAMO-ORIO AL SERIO INTERNATIONAL AIRPORT
}

\author{
Andrea Macchiavelli ${ }^{1 \star}$, Andrea Pozzi ${ }^{2}$ \\ ${ }^{1}$ University of Bergamo \& Gruppo CLAS SpA \\ ${ }^{2}$ University of Bergamo, Centre on Tourism Destinations and Heritage Interpretation (CeSTIT)
}

\begin{abstract}
:
Bergamo-Orio al Serio International Airport is the fourth busiest airport in Italy and its main characteristic is the large presence of low-cost carriers (LCCs), especially the Irish airline Ryanair. The large growth experienced by the airport has brought about new travellers and stimulated the development of local tourism, as shown by various sources. A close relationship between tourism and LCCs has been created over time, but the goals of airline companies differ from those of local tourism stakeholders and appear to be very sensitive to economic changes. The development of the route network has therefore influenced the profile of local tourists, which is now different in terms of the country of origin, purpose of travel and expenditure.
\end{abstract}

\section{Key words:}

low-cost flights, airline strategies, tourism development.

\section{INTRODUCTION}

The development of Bergamo-Orio al Serio International Airport began in 2003, when the Irish low-cost airline Ryanair launched a new base of operation basing 3 aircrafts permanently and announcing 15 routes to EU destinations with daily flights (Sacbo, 2004). Factors influencing this decision can be summarized as follows: the ground handling services suitable to minimize the turnaround time and have higher flight frequency and lower cost units (WarnockSmith and Potter, 2005; Malighetti et al., 2009), the support of local decision makers and the proximity to Milan. In the following years, the number of passengers rapidly increased, from $1.3 \mathrm{mln}$ in 2002 to $8,9 \mathrm{mln}$ in 2014. During this period the annual growth rate was higher than the national average $(17.6 \% \text { vs } 4.3 \%)^{1}$. Today, it is the fourth busiest airport in Italy after Rome-Fiumicino, Milan-Malpensa and Milan-Linate, and its main characteristic is the large presence of low-cost carriers.

The low-cost airline Ryanair also contributed to providing new travel opportunities for people living in Lombardy and nearby the airports with direct flights to Bergamo-Orio al Serio thanks to low-fare tickets, new destinations and "do-it-yourself" travel. This new demand probably moved for tourism purposes, as occurred in other Italian regions (Donzelli, 2010; Pulina \& Cortés-Jiménez, 2010; Alivernini et al., 2012a) and European areas (Lian \& Denstadli, 2010; Rey et al., 2011; Kuljanin \& Kalic, 2015). Tourism data related to the province of Bergamo - collected by the Tourism

1 own elaboration from ENAC data
Office of Bergamo Department, the Italian National Institute of Statistic (ISTAT) ${ }^{2}$ and the Bank of Italy ${ }^{3}$ - highlights the rapid growth of this sector (flows and accommodation), especially in Bergamo and its surroundings: as shown in the following paragraph, an increasing number of visitors arriving at the local airport decided to stay and visit the area.

This paper updates the analysis carried out by the Research Centre on Tourism Destinations and Heritage Interpretation (CeSTIT) of the University of Bergamo (Macchiavelli 2010; Macchiavelli \& Pozzi, 2015) and aims at highlighting the most significant facts that have characterized the development of tourism in the province of Bergamo, paying attention to foreign tourism flows arriving at the airport. Specifically, this paper will focus on:

- the close relationship between local airport development and growth experienced by the tourism sector in the province of Bergamo;

- changes occurred in the profile of local tourists, especially those determined by negative economic circumstances and strategies of LCCs;

- economic impact updated to 2014.

2 Data from the Tourism Office of Bergamo Department and ISTAT refer to the number of arrivals and overnight stays in the province of Bergamo.

3 The Bank of Italy has conducted since 1996 a survey on international tourism based on interviews and counting of resident and non-resident travellers at the Italian borders (road and rail crossings, international ports and airports) (www.bancaditalia. it). The analysis uses data regarding specifically foreign travellers at Bergamo-Orio al Serio International airport spending at least one night in accommodation facilities. 
The final paragraph will analyse the effects on local tourism policies and individuate possible options aiming at reducing negative consequences.

\section{RESULTS AND DISCUSSION}

The Alps of Bergamo region and the Lake Iseo were the most popular leisure destinations in the province of Bergamo until the end of the 90s; the city of Bergamo has a rich cultural heritage but has been renowned only among business travellers (Gruppo CLAS, 1996; Macchiavelli, 2010). The growth experienced by the local tourism sector occurred simultaneously with the large development of the local airport, and it is reasonable to assume that it is a direct consequence: Fig. 1 shows an increase in the number of tourist arrivals - especially foreigners - since 2003, when Ryanair launched a new base of operation at the local airport.

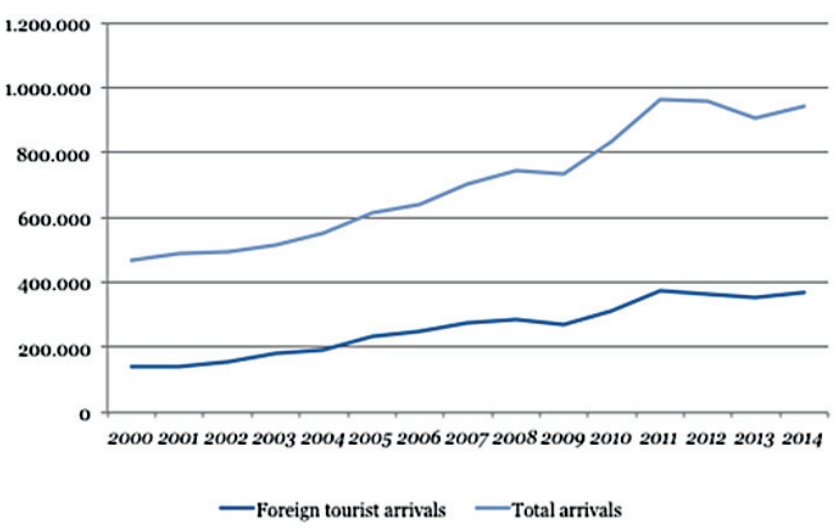

Fig. 1. Evolution of tourist arrivals in the province of Bergamo.

Source: ISTAT (2000-2013) and Tourism Office of Bergamo Department (2014).

The data are remarkable: arrivals in accommodation facilities increased by $+82.5 \%$ (from 516,965 in 2003 to
943,321 in 2014) while overnight stays only by $34.7 \%$ because of a decrease in the length of stay. The growth rate of foreign arrivals is higher than of domestic ones $(+102.3 \%$ vs $71.6 \%)$ and it is a direct consequence of the larger presence of travellers coming from abroad at the airport.

Indeed, the range of destinations from Bergamo-Orio al Serio has constantly widened in the last ten years: in 2004 there were 43 destinations in 17 countries while in 2014, 107 in 32 countries (Fig. 2). The development of the route network was influenced by different factors, but closely interrelated: the large increase in the number of flights and passengers in Europe and in Italy (ENAC and KPMG, 2011); the rapid changes in routes by LCCs, which aim at achieving the highest load factor; to a minor extent, the recent economic crisis that affects all the European countries in different periods.

Tab.1 shows that the countries of origin of tourist flows arriving at the airport have changed over time. A diversification of source markets is evident that involves also nonEuropean countries with and without direct flights to the airport.

It is noticeable that:

- Today, there are several source markets and tourist flows seem to be equally distributed between countries (Spain, United Kingdom and Germany) and areas (Eastern Europe and Russia, other European countries, non-European countries). In particular, low-cost flights appear to have become very popular also among travellers from countries without direct flights to Bergamo-Orio al Serio.

- Spain and United Kingdom are the main source markets: Spain has rapidly become the largest one and remained at the top of the ranking despite recent decrease (2010-2014); The United Kingdom was the main source market at the beginning of the airport development (2004-2006), but it registered a fall in 2010, showing a sign of recovery only since 2012 . However, both countries appear to be less important than in the past.
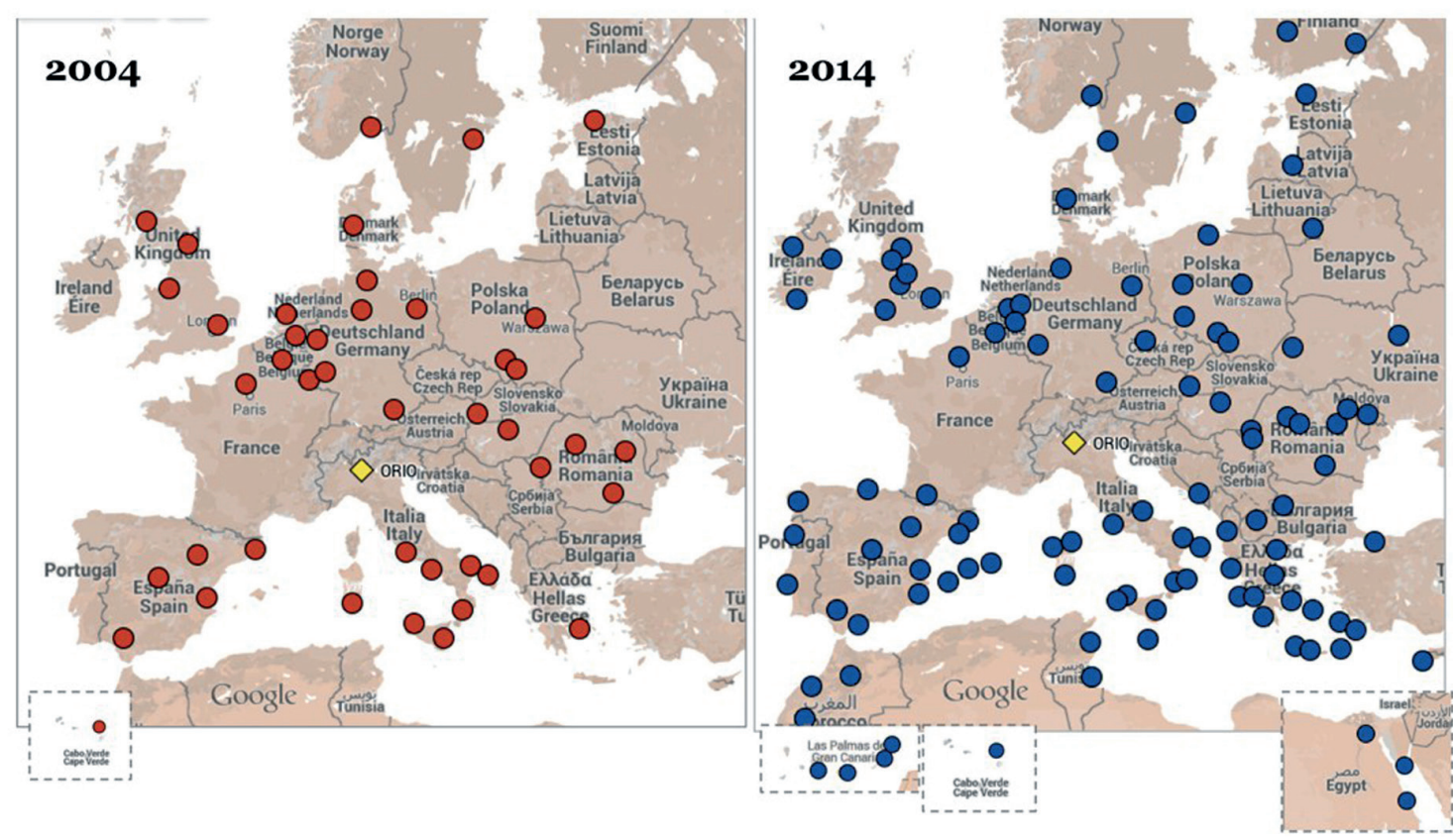

Fig. 2. Evolution of the route network from/to Bergamo-Orio al Serio. Source: Sacbo. Maps: Google maps. 
Tab.1. Evolution of shares of foreign tourism flows by country of origin. Data between parentheses refer to the shares of tourism flows with destination Bergamo.

\begin{tabular}{|c|c|c|c|c|c|c|}
\hline & 2004 & 2006 & 2008 & 2010 & 2012 & 2014 \\
\hline Spain & $\begin{array}{l}7.3 \% \\
(7.6 \%)\end{array}$ & $\begin{array}{c}18.9 \% \\
(19.4 \%)\end{array}$ & $\begin{array}{c}26.2 \% \\
(29.9 \%)\end{array}$ & $\begin{array}{c}31.7 \% \\
(34.1 \%)\end{array}$ & $\begin{array}{c}24.1 \% \\
(28.1 \%)\end{array}$ & $\begin{array}{c}16.5 \% \\
(11.7 \%)\end{array}$ \\
\hline United Kingdom & $\begin{array}{c}16.5 \% \\
(15.1 \%)\end{array}$ & $\begin{array}{c}37.1 \% \\
(41.9 \%)\end{array}$ & $\begin{array}{l}21.8 \% \\
(22 \%)\end{array}$ & $\begin{array}{c}10.4 \% \\
(10.5 \%)\end{array}$ & $\begin{array}{c}17.3 \% \\
(16.1 \%)\end{array}$ & $\begin{array}{c}12.9 \% \\
(15.2 \%)\end{array}$ \\
\hline Eastern Europe ${ }^{*}$ and Russia & $\begin{array}{c}4.2 \% \\
(1.7 \%)\end{array}$ & $\begin{array}{l}4.2 \% \\
(4.2 \%)\end{array}$ & $\begin{array}{c}12 \% \\
(11.6 \%)\end{array}$ & $\begin{array}{c}8.9 \% \\
(10 \%)\end{array}$ & $\begin{array}{c}17.6 \% \\
(18.9 \%)\end{array}$ & $\begin{array}{c}13.4 \% \\
(13.6 \%)\end{array}$ \\
\hline Germany & $\begin{array}{c}19.4 \% \\
(25.0 \%)\end{array}$ & $\begin{array}{l}10.0 \% \\
(8.7 \%)\end{array}$ & $\begin{array}{l}8.8 \% \\
(8.9 \%)\end{array}$ & $\begin{array}{l}11.1 \% \\
(10 \%)\end{array}$ & $\begin{array}{l}6.6 \% \\
(8.4 \%)\end{array}$ & $\begin{array}{l}6.5 \% \\
(8 \%)\end{array}$ \\
\hline Other European countries ${ }^{* *}$ & $\begin{array}{c}32.6 \% \\
(38.4 \%)\end{array}$ & $\begin{array}{c}21.6 \% \\
(22.9 \%)\end{array}$ & $\begin{array}{c}23.2 \% \\
(23.5 \%)\end{array}$ & $\begin{array}{c}32.1 \% \\
(31.6 \%)\end{array}$ & $\begin{array}{c}23.2 \% \\
(21.3 \%)\end{array}$ & $\begin{array}{c}30.3 \% \\
(40.5 \%)\end{array}$ \\
\hline $\begin{array}{l}\text { Non-European countries with direct } \\
\text { flights }\end{array}$ & $\begin{array}{c}0 \% \\
(0 \%)\end{array}$ & $\begin{array}{c}0 \% \\
(0 \%)\end{array}$ & $\begin{array}{c}1 \% \\
(0,3 \%)\end{array}$ & $\begin{array}{c}0.8 \% \\
(1.8 \%)\end{array}$ & $\begin{array}{c}1.6 \% \\
(1.2 \%)\end{array}$ & $\begin{array}{c}2.7 \% \\
(1.1 \%)\end{array}$ \\
\hline $\begin{array}{l}\text { Non-European countries without direct } \\
\text { flights }\end{array}$ & $\begin{array}{c}19.9 \% \\
(12.2 \%)\end{array}$ & $\begin{array}{c}8.2 \% \\
(2.9 \%)\end{array}$ & $\begin{array}{c}7 \% \\
(3.8 \%)\end{array}$ & $\begin{array}{c}5 \% \\
(2 \%)\end{array}$ & $\begin{array}{l}9.6 \% \\
(6 \%)\end{array}$ & $\begin{array}{l}17.6 \% \\
(9.8 \%)\end{array}$ \\
\hline
\end{tabular}

* Belarus, Bulgaria, Croatia, Estonia, Latvia, Lithuania, Poland, Czech Republic, Romania, Slovakia, Slovenia, Ukraine, Hungary.

** Albania, Andorra, Austria, Belgium, Denmark, Finland, France, Greece, Ireland, Island, Luxemburg, Macedonia, Malta, Moldavia, Montenegro, Norway, Netherlands, Portugal, Monaco, San Marino, Serbia, Sweden, Switzerland.

*** Cape Verde (2004); Cape Verde (2006); Cape Verde, India, Morocco and Turkey (2008); Cyprus, Morocco and Turkey (2010); Cape Verde, Cyprus, Egypt, Morocco and Turkey (2012); Cape Verde, Cyprus, Egypt, Morocco, Tunisia and Turkey (2014) (own elaboration on data from Sacbo). Source: own elaboration on data from Bank of Italy.

- It is reasonable to assume that the economic trends influenced the market share of Spain: the increase in the number of these tourists in Bergamo occurred simultaneously with the growth of Spanish economy, higher propensity to travel and the development of LCCs (ENIT, 2012a). The recent decrease (2010-2014) is a direct consequence of the crisis, which also affected outbound tourism: the number of holidays and expenditure of Spanish tourists in Italy felt in 2012 (Manente, 2013), and the increase of airport charges led Ryanair to cancel some routes and reduce the number of daily flights, also from/to Bergamo-Orio al Serio (Ryanair, 2012).

- Similarly, the depreciation of Sterling Pound (GBP) against Euro and reduction of household consumption expenditure in the United Kingdom due to the economic crisis negatively influenced propensity to travel, and the number of British tourists decreased over time in Italy (ENIT, 2012b; Alivernini et al., 2012b) and, consequently, in Bergamo.
- The countries of Eastern Europe, especially Poland, have acquired larger market share since 2004 also thanks to an increasing number of destinations and flights from/to the local airport; however, many travellers are not tourists.

The diversification of source markets changed also the profile, behaviour and expenditure of the local tourists. Tab. 2 gives an estimation of the economic impacts in the province of Bergamo and highlights the most important facts and changes.

The increase of the length of stay and reduction of tourist expenditure are strictly related to a continuous change in the profile of travellers arriving at the airport. In the province of Bergamo, high-spending leisure tourists from Western European countries (especially United Kingdom) have been replaced over time by low-spending ones from Spain and Eastern Europe. Also, the purpose of travel has changed, probably due to the crisis: tourists are less interested in cultural travels (-19.4\% in the period 2008-2014) and seem to prefer longer stays. These trends are similar

Tab. 2. Number and profile of tourists with destination Bergamo.

\begin{tabular}{lcccccc}
\hline & 2004 & 2006 & 2008 & 2010 & 2012 & 2014 \\
\hline Arrivals (estimated value) & 103,300 & 190,305 & 268,244 & 316,870 & 198,417 & 161,269 \\
\hline $\begin{array}{l}\text { Overnight stays estimated } \\
\text { (estimated value) }\end{array}$ & 571,069 & 508,933 & 901,385 & $1,472,661$ & 939,066 & 758,781 \\
\hline Length of stay (days) & 5.5 & 2.7 & 3.4 & 4.6 & 4.7 & 4.7 \\
\hline $\begin{array}{l}\text { Average daily expenditure per } \\
\text { capita }\end{array}$ & $€ 74.9$ & $€ 97.1$ & $€ 81.7$ & $€ 57.0$ & $€ 63.8$ & $€ 67.7$ \\
\hline for accommodation & $€ 45.9$ & $€ 40.1$ & $€ 31.7$ & $€ 25.3$ & $€ 28.7$ & $€ 26.3$ \\
\hline Total tourist expenditure & $€ 42,768,607$ & $€ 49,425,404$ & $€ 73,617,370$ & $€ 83,943,010$ & $€ 59,955,685$ & $€ 51,379,813$
\end{tabular}

Source: own elaboration on data from Bank of Italy. 
to those registered among tourist flows arriving at the airport, but less accentuated (cultural travels: $-4.8 \%$; mountain holidays: $+0.6 \%$; lake holidays: $+2.6 \%$ ); the only difference is the number of tourists visiting friends and relatives, which increases only among the second group (+3.4\%) because of the growth of travellers moving to other provinces $(+1.9 \%$ in the period 2008-2014) and outside Lombardy (+5.5\%). In addition, these new tourists tend to prefer cheaper and flexible accommodations in the city and its surroundings, such as Bed and Breakfast, apartments and agritourisms (Macchiavelli \& Licandri, 2013); the decrease of the accommodation expenditure (Tab. 2) highlights this trend. The consequence of these facts and changes is smaller economic benefit to the territory after the crisis.

\section{SUMMARY}

The data show a close relationship between the local airport development and growth experienced by the tourism sector, as an increasing number of travellers decided to stay in the province of Bergamo for tourism purposes. The higher international visibility of the airport positively influenced attractiveness, especially among foreigners, and today Bergamo and its province can be considered holiday destinations.

However, the analysis also shows a dependency between LCCs strategies and local tourism: the diversification of source markets and changes in the profile of tourists are consequences of the development of the route network. LCCs aim at opening profitable routes and increasing their market shares, and seem to be very sensitive to economic trends (e.g. Ryanair in Spain). It is therefore reasonable to assume that these two facts (LCCs strategies and economy) will influence local tourism flows in the future.

In order to reduce negative impacts on tourism sector local stakeholders and the airport operator (Sacbo) should work together. LCCs strategies and economic changes are macroeconomic phenomena, and local policies tend to have little influence on them. Thereby, local stakeholders should be aware of these facts and develop adequate strategies. The first one may include common actions aiming at incentivizing the main airlines to choose routes more interesting for local tourism, also by using subsidies more carefully. The second one may regard marketing activities, for example, considering focused actions with a double approach (incentives for markets suffering a bad economic situation and promotional activities for new destinations connected to the airport).

\section{REFERENCES}

Alivernini, A., D’Ignazio, A., \& Migliardi, A. (2012a). Cheap flights to smaller cities: good news for local tourism? Retrieved April 5, 2015, from http://www.congress. is/11thtourismstatisticsforum/papers/Andrea_Alivernini.pdf

Alivernini, A., Breda, E., \& Iannario, E. (2012b). Quindici anni di turismo internazionale in Italia. In: Il turismo internazionale in Italia: dati e risultati. Retrieved April 5, 2015, from http://www.bancaditalia.it/pubblicazioni/ collana-seminari-convegni/2013-0012/n.12_turismo_ internazionale.pdf
Donzelli, M. (2010). The effect of low-cost air transportation on the local economy: evidence from Southern Italy. Journal of Air Transport Management, 16 (3), 121-126. doi:10.1016/j.jairtraman.2009.07.005

ENAC-Ente Nazionale per l'Aviazione Civile. (2015). Dati di traffico. Years 2003-2014, Roma.

ENAC-Ente Nazionale per l'Aviazione Civile and KPMG (2011). Evoluzione del traffico low cost a livello europeo e nazionale. Retrieved April 5, 2015, from http://www. enac.gov.it/repository/ContentManagement/information/N170143071/Studio_sull'evoluzione_del_traffico_ low_cost_a_livello_europeo_e_nazionale.pdf

ENIT-Ente Nazionale del Turismo (2012a). Spagna. Rapporto Congiunto Ambasciata/ENIT 2012, Roma.

ENIT-Ente Nazionale del Turismo (2012b). Regno Unito. Rapporto Congiunto Ambasciata/Consolati/ENIT 2012, Roma.

Gruppo CLAS. (1996). Turismo culturale e turismo d'affari: un rapporto difficile in Lombardia? Milano: Unioncamere Lombardia.

Kuljanin, J., \& Kalic, M. (2015). Exploring characteristics of passengers using traditional and low-cost airlines: a case study of Belgrade Airport. Journal of Air Transport Management, 46, 12-18. doi:10.1016/j.jairtraman.2015.03.009

Lian, J.I., \& Denstadli, J.M. (2010). Booming leisure air travel to Norway is the role of airline competition. Scandinavian Journal of Hospitality and Tourism, 10 (1), 1-15. doi: 10.1080/15022250.2010.484215

Macchiavelli, A. (2010). Focus. Bergamo da città industriale a polo turistico. In IRER-Istituto regionale di ricerca della Lombardia. Lombardia Rapporto di legislatura, Guerini e Associati.

Macchiavelli, A., \& Licandri, S. (2013). Alla ricerca di una ricettività low cost: tentativi di risposta nell'area bergamasca. Rivista di Scienze del Turismo, 4 (1-2), 103-116. doi: 107358/rst 2013-01-02-macc.

Macchiavelli, A., \& Pozzi, A. (2015). Low-cost flights and changes in tourism flows: evidence from BergamoOrio Al Serio international. In H. Pechlaner and E. Smeral (Ed.), Tourism and Leisure: Current Issues and Perspectives of Development (pp. 323-336). Wiesbaden: Springer.

Malighetti, P, \& Paleari, S., \& Redondi, R. (2009). Pricing strategies of low cost airlines: The Ryanair case study. Journal of Air Transport Management, 15 (4), 195-203. doi:10.1016/j.jairtraman.2008.09.017

Manente, M. (2013). Economia turistica regionale nel 2012. In L'Italia e il turismo internazionale. Andamento incoming e outgoing nel 2012, Venezia, $17^{\text {th }}$ April 2013, slides.

Pulina, M., \& Cortes-Jimenez, I. (2010). Have low-cost carriers influenced tourism demand and supply? The case of Alghero. Tourism Analysis, 15 (6), 617-635.

Rey, B., Myro, R., \& Galera, A. (2011). Effect of low-cost airlines on tourism in Spain. A dynamic panel data model. Journal of Air Transport Management, 17 (3), 163-167. doi:10.1016/j.jairtraman.2015.03.009

Sacbo spa. (2015).Bilancio d'esercizio. Years 2003-2014, Bergamo.

Warnock-Smith, D., \& Potter, A. (2005). An exploratory study into airport choice factors for European low-cost airlines. Journal of Air Transport Management, 11 (6), 388-392. doi:10.1016/j.jairtraman.2005.05.003 